(B. A. I. Order No. 304)

United States Department of Agriculture

BUREAU OF ANIMAL INDUSTRY

\title{
REGULATIONS GOVERNING THE RECOGNITION OF BREEDS AND PUREBRED ANIMALS
}

\section{United States Department of Agriculture,}

OfFICE OF THE SECRETARY.

Under authority of paragraph $\mathbf{1 5 0 6}$ of the act of Congress approved September 21,1922 , entitled "An act to provide revenue, to regulate commerce with foreign countries, to encourage the industries of the United States, and for other purposes" (42 Stat. 858, 923), ${ }^{1}$ the following regulations are issued governing the recognition of breeds and purebred animals imported into the United States for breeding purposes. For purposes of identification these regulations are designated as B. A. I. Order 304 and supersede all previous regulations on the same subject. They shall become and be effective on and after April 15, 1927.

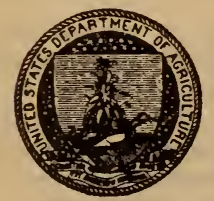

Done at Washington this 23d day of February, 1927.

Witness my hand and the seal of the Department of Agriculture.

\section{R. IV. DUNLAP, \\ Acting Secretary of Agriculture.}

\section{REGULATION 1.-CERTIFICATION OF PUREBRED ANIMALS}

SEction 1. Bureau of Animal Industry to issue certificates.-The Bureau of Animal Industry of the Department of Agriculture is hereby authorized to issue certificates of pure breeding under the provisions of this order.

SEction 2. How to obtain certificates. - In order to obtain such certificates of pure breeding, importers shall conform to the following procedure:

Paragraph 1. Application for certificates.-An application for certificates shall be made to the Bureau of Animal Industry on forms furnished or approved by the department, showing the number of animals imported, the breed and sex, the port of entry into the United States, customs entry number, the name of ressel or carrier by which shipped, and the date of arrival. This application may be signed by either the owner, the importer, or the agent, stating the name and address (in the United States) of the owner of the animal or animals. (A. H. Form 105- "Application for certificates" will be furnished upon request.)

Paragraph 2, Certificates of pedigree.-Certificates of pedigree for such animals, issued by the custodian of one of the books of record given in Regulation 2, section 4, of this order, shall be furnished to the Bureau of Animal Industry.

Paragraph 3. Affidavit of identity.-A duly acknowledged affidavit from the owner, agent, or importer that the animals so imported are the identical animals described in the certificates of pedigree must be furnished. (A. H. Form 283- "Affidavit of identity" will be furnished on request.)

Paragraph 4. Ownership.-Complete transfer of ownership of imported animals from the breeder to the importer must be shown, such transfers to be either officially recorded by the registry associations issuing certificates, or on official certificates of transfer of such associations.

Section 3. Applications will be given consideration in the order in which they are received. When the application and accompanying papers are

${ }^{1}$ Paragraph 1506 of the tariff act of 1922 is quoted on pp. 5 and 6 of this order. $36682-27^{\circ}$ 
satisfactory, certificates to that effect will be issued and forwarded to the collector of customs at the port of entry and the pedigree certificates returned to the importer or his agent. However, the certificates of pure breeding of the Bureau of Animal Industry will not be issued until the descriptions of the animals, submitted by an inspector of the Bureau of Animal Industry at the port of entry, are received in Washington. All papers for animals which do not meet the requirements of this order will be retained or returned, at the discretion of the department.

Section 4. Eligibility of animals.-Where the provisions of this order have been otherwise complied with, animals will be certified as purebred which have been fully registered in good faith in one of the books of record for one of the recognized breeds given in Regulation 2, section 4, of this order, except those which have been registered on inspection.

\section{REGULATION 2.-RECOGNITION OF ADDITIONAL BREEDS}

Section 1. Application for recognition.-Before an additional breed to those shown in section 4 of this regulation shall be added to this order the custodian of its book of record shall submit to the department a complete set of the published volumes of such books of record to date of making application, together with all rules and forms in force on said date affecting the registration of animals in said book of record. The department will consider the case on its merits and use such information as may be available to determine whether the breed is a recognized breed and whether the animals registered in the book of record are purebred.

SECTION 2. Official communications.-All official communications submitted under the provisions of this order should be addressed to the Chief of the Bureau of Animal Industry, Department of Agriculture, Wash ngton, D. C., except as mentioned below.

SECTION 3. Books of record required.-Custodians of books of record for recognized breeds shall forward volumes of their books of record. as soon as published, addressed to the Chief of the Bureau of Animal Industry, in care of the United States Dispatch Agent, 2 Rector Street, New York, N. Y., U. S. A.

SECTION 4. Recognized breeds. - The following breeds of domestic animals are recognized. Opposite will be found the names of the foreign books of record for these breeds, with the names and addresses of their custodians.

Paragraph 1. Recognized breeds and books of record across the seas.

CATTLE

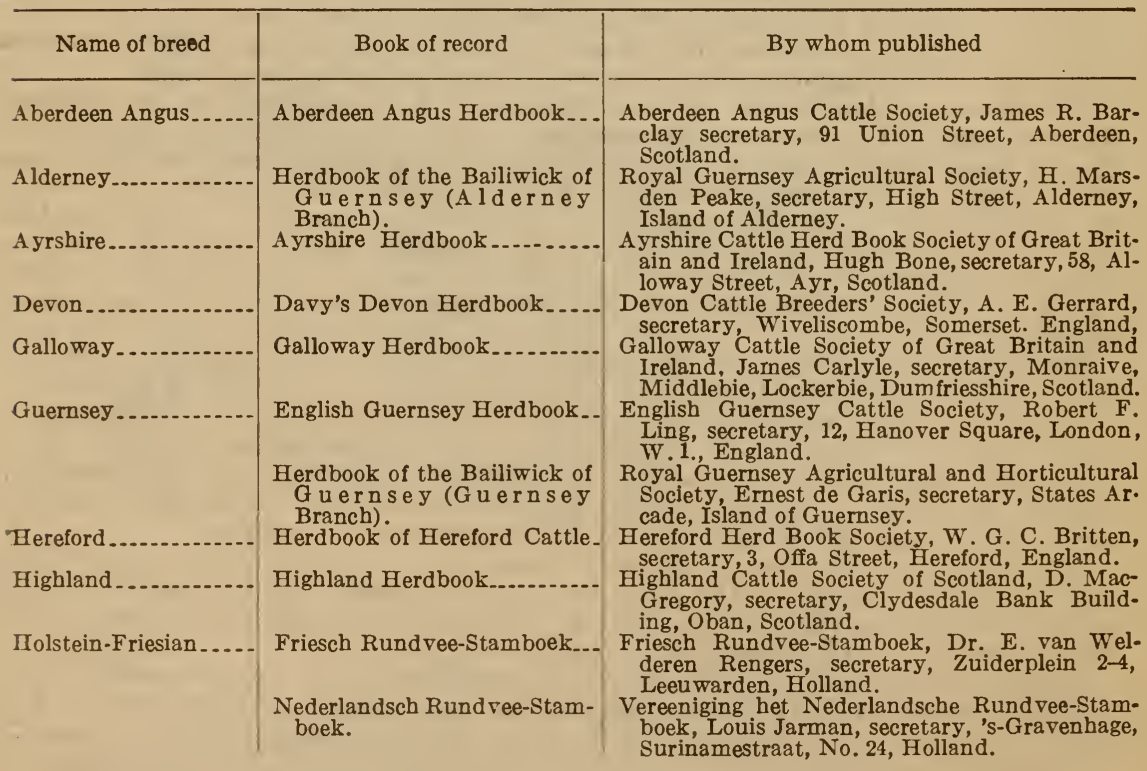


CATTLE-Continued

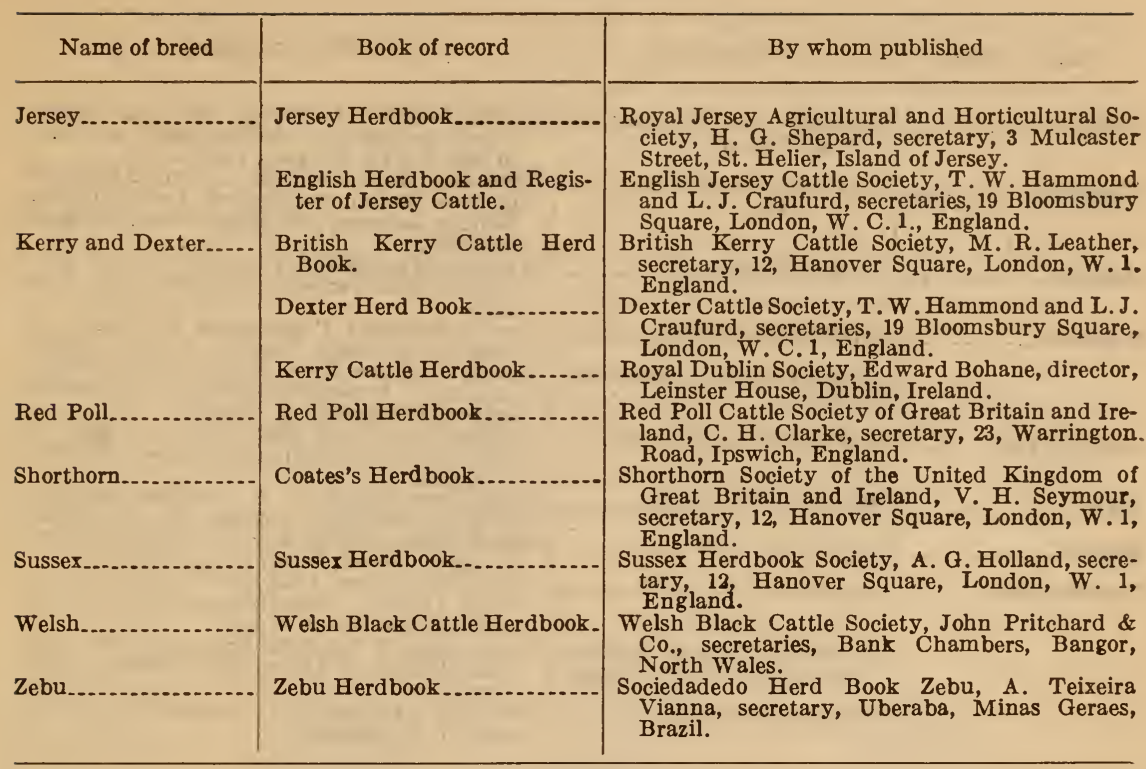

SHEEP

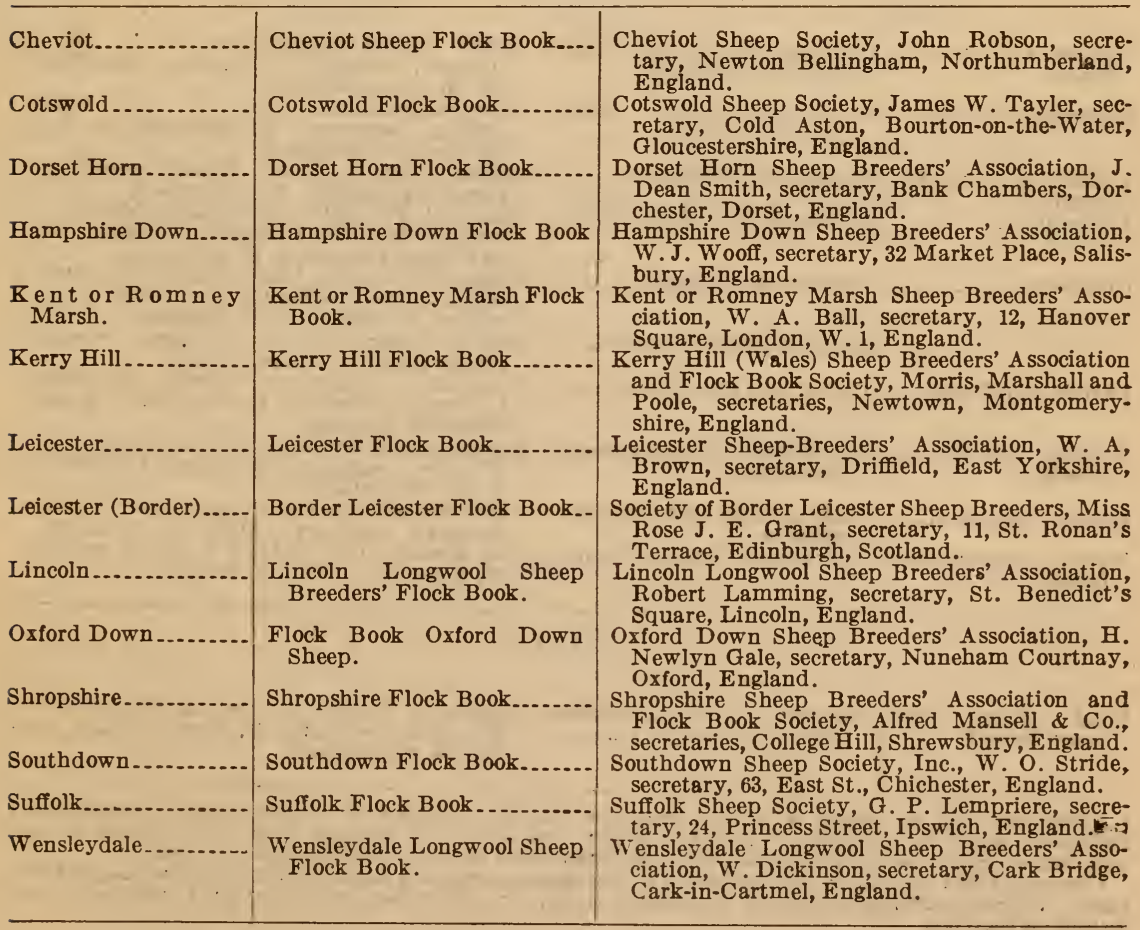


HORSES

\begin{tabular}{|c|c|c|}
\hline Name of breed & Book of record & By whom published \\
\hline $\begin{array}{l}\text { Clydesdale....... } \\
\text { Hackney......... } \\
\text { Percheron........ } \\
\text { Shetland Pony... } \\
\text { Shire............. } \\
\text { Suffolk............ } \\
\text { Thoroughbred... }\end{array}$ & $\begin{array}{l}\text { Hackney Studbook........... } \\
\text { Studbook Percheron de France } \\
\text { British Percheron Horse Stud } \\
\text { Book. } \\
\text { Shetland Pony Studbook..... } \\
\text { Shire Horse Studbook........ } \\
\text { Suffolk Studbook............. } \\
\text { Australian Studbook 2......... } \\
\text { Studbook Français Registre } \\
\text { des Chevaux de Pur Sang.2 } \\
\text { General Stud Book............. }\end{array}$ & $\begin{array}{l}\text { Société Royale "Le Cheval de Trait Belge," } \\
\text { Chevalier Hynderick de Theulegoet, secretary, } \\
20 \text { Rue Royale, Brussels, Belgium. } \\
\text { Clydesdale Horse Society of the United Kingdom } \\
\text { of Great Britain and Ireland, Archibald Mac- } \\
\text { Neilage, secretary, 93, Hope Street, Glasgow, } \\
\text { Scotland. } \\
\text { Hackney Horse Society, Robert F. Ling, secre-- } \\
\text { tary, 12, Hanover Square, London, W.1, Eng- } \\
\text { land. } \\
\text { Société Hippique Percheronne de France, E. } \\
\text { Lemarie, secretary, Nogent-le-Rotrou, France. } \\
\text { British Percheron Horse Society, A. W. Hewet, } \\
\text { secretary, Imperial House, 27, Cavendish } \\
\text { Square, London, W. 1, England. } \\
\text { Shetland Pony Stud Book Society, Robert W. } \\
\text { Walker, secretary, } 3 \text { Golden Square, Aberdeen, } \\
\text { Scotland. } \\
\text { Shire Horse Society, A. B. Charlton, secretary, } \\
\text { 12, Hanover Square, London, W. 1, England. } \\
\text { Suffolk Horse Society, Raymond Keer, secretary, } \\
\text { 6, Church Street, Woodbridge, England. } \\
\text { Australian Jockey Club and Victoria Racing } \\
\text { Club, Leslie G. Rouse, keeper, 6, Bligh Street, } \\
\text { Sydney, New South Wales. } \\
\text { Commission de Studbook Français de Pur Sang, } \\
\text { The Minister of Agriculture, president, Paris, } \\
\text { France. } \\
\text { Weatherby \& Sons, 15, Cavendish Square, Lon- } \\
\text { don, W. 1, England. }\end{array}$ \\
\hline
\end{tabular}

\section{DOGS 3}

Various recognized breeds.

Dobermannpinscher . .

Various recognized breeds.

Foxhound.

Greyhound

Harrier and Beagle....

Various recognized breeds.

German Shepherd....

Various recognized breeds.
Livre des Origines de la Société Royale Saint-Hubert.

Dobermannpinscher Zuchtbuch (D. P. Z.).

Kennel Club Studbook.......

Foxhound Kennel Studbook.-

Greyhound Studbook.

Irish Greyhound Studbook

Harrier and Beagle Studbook.

Schweizer is ches HundeStammbuch.

Zuchtbuch für deutsche Schaferhunde.

Irish Kennel Club Studbook.
Société Royale Saint-Hubert, G. C. W. F. O'Breen, secretary, Chaussée Saint-Pierre, 391, Brussels, Belgium.

Dobermannpinscher-Verein (D. V.), Philipp Grünig, secretary, Ferdinandstrasse 51-53, Hamburg, 1, Germany.

Kennel Club, H. T. W. Bowell, secretary, 84, Piccadilly, London, W. 1, England.

Master of Foxhounds Association, Major Cecil Pelham, secretary, 8 Breams Building, Chancer y Lane, London, S. E. 4, England.

National Coursing Club, Horace A. Groom, keeper of the Greyhound Stud Book, 11, Haymarket, London, S. W. 1, England.

Irish Coursing Club, T. A. Morris, secretary, Bridge Street, Clonmel, Ireland.

Association of Masters of Harriers and Beagles, J. Pawle, secretary, Havers Park, Bishop's Stortford, England.

Schweizerische Kynologischen Gesellschaft, Carl Wittwer, secretary, Waldegg, Liebefeld b. Bern, Switzerland.

Verein für deutsche Schaferhunde,Herr Schaeller, secretary, Augsburg 3, München, Germany.

Irish Kennel Club, Richard G. Quirk, secretary, 23, Eden Quay, Dublin, Ireland.

\section{CATS}

\begin{tabular}{l|l|l}
\hline Long $\begin{array}{l}\text { Haired } \\
\text { Short Haired. }\end{array}$ & $\begin{array}{c}\text { Register of the Governing } \\
\text { Council of the Cat Fancy. }\end{array}$ & $\begin{array}{c}\text { Governing Council of the Cat Fancy, H. O. } \\
\text { Edmonds, secretary, 69, Hornsey Rise, Lon- } \\
\text { don, N. 19, England. }\end{array}$ \\
\hline
\end{tabular}

2 Provided that no animal or animals registered in the Australian or in the French Thoroughbred studbooks shall be certified as purebred unless such animal or animals trace in all crosses to animals which are proved to the satisfaction of the department to be of the Thoroughbred breed.

Provided that no dog or dogs registered in the above-mentioned books shall be certified as purebred unless a three-generation certificate of pedigree issued by one of the above-mentioned societies is submitted for each dog. 
HoGs

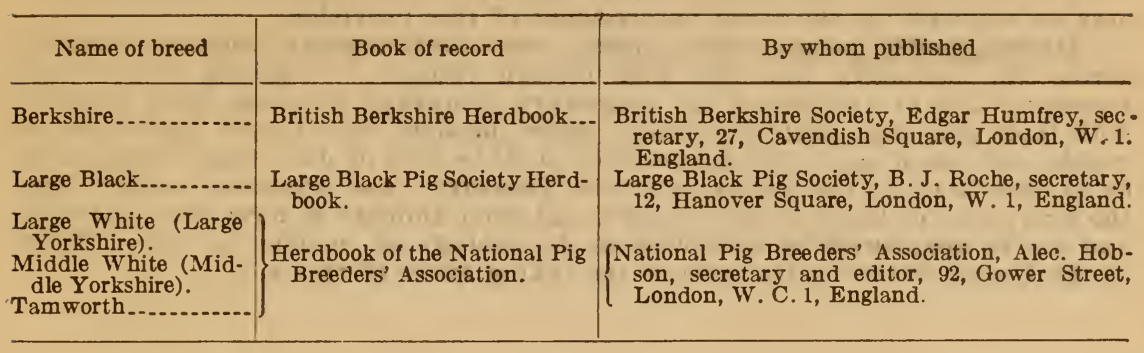

Paragraph 2. Recognized breeds and books of record in Canada.-The Canadian National Records are recognized for the following breeds: Provided, That no animal or animals registered in the Canadian National Records shall be certified by the Secretary of Agriculture as purebred unless such animal or animals trace, in all crosses, to animals which are proved to the satisfaction of the department to be of the same breed:

\begin{tabular}{|c|c|c|c|}
\hline Cattle & Sheep & Horses & Hogs \\
\hline $\begin{array}{l}\text { Aberdeen Angus. } \\
\text { Ayrshire. } \\
\text { Brown Swiss. } \\
\text { French Canadian. } \\
\text { Galloway. } \\
\text { Guernsey. } \\
\text { Hereford. } \\
\text { Jersey. } \\
\text { Red Poll. } \\
\text { Shorthorn. }\end{array}$ & $\begin{array}{l}\text { Cheviot. } \\
\text { Cotswold. } \\
\text { Dorset Horn. } \\
\text { Hampshire. } \\
\text { Leicester. } \\
\text { Lincoln. } \\
\text { Oxford Down. } \\
\text { Shropshire. } \\
\text { Southdown. } \\
\text { Suffolk. }\end{array}$ & $\begin{array}{l}\text { Belgian Draft. } \\
\text { Clydesdale. } \\
\text { Hackney. } \\
\text { Percheron. } \\
\text { Shetland. } \\
\text { Shire. } \\
\text { Standardbred. } \\
\text { Suffolk. } \\
\text { Thoroughbred. } \\
\text { Welsh Pony and Cob. }\end{array}$ & $\begin{array}{l}\text { Berkshire. } \\
\text { Chester White. } \\
\text { Duroc-Jersey. } \\
\text { Hampshire. } \\
\text { Large Black. } \\
\text { Poland China. } \\
\text { Tamworth. } \\
\text { Yorkshire. }\end{array}$ \\
\hline
\end{tabular}

Paragraph 3.-The Canadian Kennel Club (Canadian National Records) is recognized for all the breeds of dogs registered in said records: Provided, That no dog or dogs registered in said records shall be certified as purebred unless a three-generation certificate of pedigree issued by said Canadian National Records is submitted for each dog.

Paragraph 4.-The Holstein-Friesian Association of Canada, of which W. A. Clemons, of Brantford, Ontario, Canada, is secretary and editor, is recognized for the Holstein-Friesian breed registered in the Holstein-Friesian Herd Book of that association.

Paragraph 1506 of the act of Congress entitled "An act to provide revenue, to regulate commerce with foreign countries, to encourage the industries of the United States, and for other purposes," approved September 21, 1922 (42 Stat. 858, 923), is as follows:

"1506. Any animal imported by a citizen of the United States specially for breeding purposes, shall be admitted free, whether intended to be used by the importer himself or for sale for such purposes, except black or silver foxes: Provided, That no such animal shall be admitted free unless purebred of a recognized breed and duly registered in a book of record recognized by the Secretary of Agriculture for that breed: Provided further, That the certificate of such record and pedigree of such animal shall be produced and submitted to the Department of Agriculture, duly authenticated by the proper custodian of such book of record, together with an affidavit of the owner, agent, or importer that the animal imported is the identical animal described in said certificate of record and pedigree. The Secretary of Agriculture may prescribe such regulations as may be required for determining the purity of breeding and the identity of such animal: And provided further, That the collectors of customs shall require a certificate from the Department of Agriculture stating that such animal is purebred of a recognized breed and duly registered in a book of record recognized by the Secretary of Agriculture for that breed. 
"The Secretary of the Treasury may prescribe such additional regulations as may be required for the strict enforcement- of this-provision.

"Horses, mules, asses, cattle, sheep, and other domestic animals straying across the boundary line into any foreign country, or driven across such boundary line by the owner for temporary pasturage purposes only, together with their offspring, shall be dutiable unless brought back to the United States within eight months, in which case they shall be free of duty under regulations to be prescribed by the Secretary of the Treasury: And provided further, That the prorisions of this act shall apply to all such animals as have been imported and are in quarantine or otherwise in the custody of customs or other officers of the United States at the date of the taking effect of this act."

ADDITIONAL COPIES

OF THIS PUBLICATION MAT BE PROCURED FROM

THE SUPERINTENDENT OF DOCUMENTS

GOVERNKENT PRINTING OFTICE

WASHINGTON, D. C.

$\Delta T$

5 CENTS PER COPY

$\nabla$ 



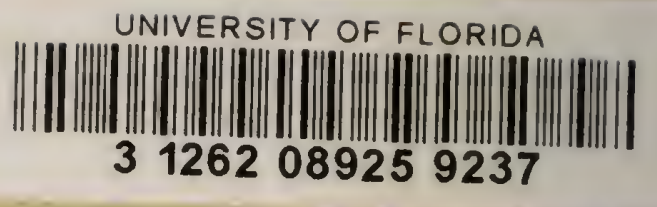

